\title{
Journal of Health Education
}

\section{History of Fish-Based Complementary Food Provision Toward Children's Cognitive Level in Elementary School}

\author{
Alberto Diliano Novelito Nahak, Yoseph Leonardo Samodra ${ }^{\varpi}$, Istianto Kuntjoro
}

Faculty of Medicine, Duta Wacana Christian University, Indonesia

\section{Article Information \\ Article History: \\ Submitted: February 2019 \\ Accepted: March 2019 \\ Published: April 2019}

\section{Keywords:}

Cognitive level;

fish-based complementary

food:

elementary school

\begin{abstract}
Background: Nutritional components contained in fish like essential fatty acid might support the growth and development of children's brain. Therefore, it's better to give it as early as possible at the age of 6-24 months as complementary food because this age was the ideal age for the growth and development of children's cognitive intelligence. The aim of this study was to find out the correlation between fish-based complementary food history with children's cognitive level.

Methods: This study used cross sectional design with 59 students from 4th grade Budya Wacana Elementary School Yogyakarta were selected as participant in this study. Data were collected by IQ test (CFIT 2B scale) and validated questionnaire.

Results: Statistical bivariate analysis by spearman rank test showed a correlation between fish-based complementary food history ( $p=0.031$ ), parental assistance ( $p=0.022$ ), exclusive breastfeeding history $(p<0.01)$ with children's cognitive level. There were no correlation between parenting style $(p=0.683)$, mother's knowledge about complementary food $(p=0.374)$, and education $(p=0.902)$ with cognitive level. Statistical analysis by logistic regression test showed that exclusive breastfeeding history $(p=0,03)$ has stronger correlation to cognitive level compared to fish-based complementary food history ( $p=$ $0,155)$ and parental assistance $(p=0,167)$.

Conclusion: There is correlation that is clinically significant but not statistically significant between fishbased complementary food history and parental care with children's cognitive level. Exclusive breastfeeding history has a stronger correlation that clinically and statistically significant to children's cognitive level.
\end{abstract}




\section{BACKGROUND}

Fish-based complementary food is weaning food given to children aged 6-24 months to support children's growth and development. Fish-based complementary food mostly contained essential fatty acids in the form of omega-3 and DHA (Docosahexaenoic Acid) which play roles in the process of brain growth and development, improve nerve work, brain intelligence, and memory (Andriani \& Wirjatmaji, 2012). In addition, consumption of EPA and DHA can also reduce the risk and prevent several diseases including arthritis, inflammation, cancer, and psychological conditions (Larsen, Eilertsen, \& Elvevoll, 2011). Factors that influence children's cognitive level are genetic and environmental factors. Genetic factors are factors that are derived directly from parents. Environmental factors are factors that can be manipulated. Environmental factors consist of 3 aspects, namely fostering, compassion, and sharpening. Foster care is related to parenting and nutrition given. Compassion is related to the love given by parents so that it can affect children's growth and cognitive development. Sharpening is related to stimulation that can stimulate growth and cognitive development (Soetjiningsih, 2013). This study aimed to find out the correlation between fish-based complementary food history with children's cognitive level

\section{METHODS}

This study used a correlative analytic design with cross sectional design. The study population was a number of 152 students from Budya Wacana Elementary School Yogyakarta.
Sample was 59 students from 4th grade Budya Wacana Elementary School Yogyakarta. The independent variables in this study are parenting, mother's knowledge about complementary foods for breast milk, the implementation of parental affection, the impelentation of formal and informal education, and exclusive breastfeeding history. The dependent variable is the cognitive level of students as measured by IQ tests. This study used bivariate data analysis of spearman rank test to determine the correlation of independent and confounding variables with dependent variables and multivariate data analysis of logistic regression test to determine the variables that most influence the cognitive level of children.

\section{RESULTS AND DISCUSSION}

Table 1 shows the data distribution of the implementation of parenting in 4th grade Budya Wacana Elementary School Yogyakarta, most of the students, 42 students (71.2\%) had enough parenting. Students who received less parenting were $11(18.6 \%)$ students, while $6(10.2 \%)$ students got good parenting. The distribution of mother's knowledge about complementary foods for breast milk was mostly (52.5\%) mothers, with a total of 31 people having good knowledge about fish-based complementary food. Mothers who had poor knowledge about complementary foods for breast milk were 28 (47.5\%) people. The distribution of the implementation of parental affection to the 4 th grade students of Budya Wacana Elementary School Yogyakarta shows that students left for $\leqq 6$ hours were 35 (59.3\%) and students who were left by mothers for $>6$ hours were 24 (40.7\%). 
Distribution of the implementation of formal (in school) and informal (outside school) education to 4th grade students of Budya Wacana Elementary School Yogyakarta is known that students who only got formal education were only 39 (66.1\%) students. Students who got formal and informal education were $20 \quad(33.9 \%)$ students. The distribution of history of exclusive breastfeeding to 4 th grade students of Budya Wacana Elementary School Yogyakarta revealed that students who received exclusive breastfeeding were 39 (66.1\%) and those who did not get exclusive breastfeeding as much as $20(33.9 \% 3)$. Distribution of IQ test results for 4th grade students of Budya Wacana
Elementary School Yogyakarta, which are divided into 8 categories, shows that most students get IQ test results on average, which was 22 (37.3\%) students. Students who got IQ test results in very intelligent category were 3 people (5.1\%). Students who get IQ test results in the smart category were 7 people (11.9\%). Students who get IQ test results with category above the average were 15 people (25.4\%). Students who get IQ test results with category below the average were 6 people (10.2\%). Students who get IQ test results in borderline categories were 5 people (8.5\%). Students who get IQ test results in the mentally defective category were 1 person (1.7\%).

Table 1. Distribution of respondents based on variables

\begin{tabular}{|c|c|c|c|}
\hline Variables & Categories & Frequency & Percentage \\
\hline \multirow[t]{3}{*}{ Parenting } & Less & 11 & $18,6 \%$ \\
\hline & Enough & 42 & $71,2 \%$ \\
\hline & Good & 6 & $10,2 \%$ \\
\hline Mother's knowledge & Less & 28 & $47,5 \%$ \\
\hline complementary food & Good & 31 & $52,5 \%$ \\
\hline \multirow[t]{2}{*}{ Implementation of parental care } & $\begin{array}{l}\text { Left by the mother for } \leqq 6 \\
\text { hours }\end{array}$ & 35 & $59,3 \%$ \\
\hline & Left by the mother for $>6$ jam & 24 & $40,7 \%$ \\
\hline \multirow[t]{2}{*}{$\begin{array}{l}\text { Implementation of formal and } \\
\text { informal education }\end{array}$} & Only get formal education & 39 & $66,1 \%$ \\
\hline & $\begin{array}{l}\text { Get formal and informal } \\
\text { education }\end{array}$ & 20 & $33,9 \%$ \\
\hline \multirow[t]{2}{*}{ History of exclusive breastfeeding } & $\begin{array}{l}\text { Complete exclusive } \\
\text { breastfeeding }\end{array}$ & 39 & $66,1 \%$ \\
\hline & $\begin{array}{l}\text { Incomplete exclusive } \\
\text { breastfeeding }\end{array}$ & 20 & $33,9 \%$ \\
\hline \multirow[t]{7}{*}{ IQ test results } & Mentally defective & 1 & $1,7 \%$ \\
\hline & Borderline & 5 & $8,5 \%$ \\
\hline & Below average & 6 & $10,2 \%$ \\
\hline & Average & 22 & $37,3 \%$ \\
\hline & Above average & 15 & $25,4 \%$ \\
\hline & Smart & 7 & $11,9 \%$ \\
\hline & Highly intelligent & 3 & $5,1 \%$ \\
\hline
\end{tabular}


Table 2. Results of the correlation between the history provision of fish-based complementary food, the history of exclusive breastfeeding and maternal care or compassion with cognitive level

\begin{tabular}{|c|c|c|c|c|c|c|c|c|c|}
\hline \multirow[b]{2}{*}{ Variables } & \multicolumn{7}{|c|}{ Cognitive level } & \multirow{2}{*}{$\begin{array}{c}p \\
\text { val } \\
\text { ue }\end{array}$} & \multirow{2}{*}{$\begin{array}{c}\text { Correlation } \\
\text { coefficient } \\
(\mathbf{r})\end{array}$} \\
\hline & $\begin{array}{l}\text { Mentally } \\
\text { defective }\end{array}$ & Borderline & $\begin{array}{c}\text { Below } \\
\text { average }\end{array}$ & Average & $\begin{array}{l}\text { Above } \\
\text { average }\end{array}$ & Smart & $\begin{array}{c}\text { Highly } \\
\text { intelligent }\end{array}$ & & \\
\hline Never & 1 & 2 & 3 & 9 & 1 & 2 & 0 & \multirow{4}{*}{0,031} & \multirow{4}{*}{0,280} \\
\hline Few times & 0 & 0 & 0 & 5 & 4 & 0 & 1 & & \\
\hline Rare & 0 & 2 & 3 & 4 & 9 & 2 & 1 & & \\
\hline Often & 0 & 1 & 0 & 4 & 1 & 3 & 1 & & \\
\hline$\leqq 6$ hours & 1 & 4 & 6 & 6 & 3 & 0 & 1 & \multirow{2}{*}{0,022} & \multirow{2}{*}{0,298} \\
\hline$>6$ hours & 0 & 1 & 1 & 16 & 12 & 7 & 2 & & \\
\hline $\begin{array}{l}\text { Exclusive } \\
\text { breastfeeding }\end{array}$ & 1 & 3 & 4 & 9 & 5 & 2 & 0 & \multirow{2}{*}{$<0,01$} & \multirow{2}{*}{0,459} \\
\hline $\begin{array}{l}\text { No exclusive } \\
\text { breastfeeding }\end{array}$ & 0 & 2 & 2 & 13 & 10 & 5 & 3 & & \\
\hline
\end{tabular}

Table 3. Result of the correlation between parenting, the provision of additional education (sharpening), maternal knowledge about complementary foods for breast milk with cognitive level

\begin{tabular}{|c|c|c|c|c|c|c|c|c|c|}
\hline \multirow[b]{2}{*}{ Variables } & \multicolumn{7}{|c|}{ Cognitive level } & \multirow[b]{2}{*}{$\begin{array}{c}p \\
\text { value }\end{array}$} & \multirow{2}{*}{$\begin{array}{c}\text { Correlation } \\
\text { coefficien } \\
(\mathbf{r})\end{array}$} \\
\hline & $\begin{array}{l}\text { Mentally } \\
\text { defective }\end{array}$ & Borderline & $\begin{array}{c}\text { Below } \\
\text { average }\end{array}$ & Average & $\begin{array}{c}\text { Above } \\
\text { average }\end{array}$ & Smart & $\begin{array}{c}\text { Highly } \\
\text { intelligent }\end{array}$ & & \\
\hline Less & 0 & 1 & 2 & 4 & 2 & 2 & 0 & & \\
\hline Enough & 1 & 2 & 3 & 17 & 11 & 5 & 3 & 0,683 & $-0,054$ \\
\hline Well & 0 & 2 & 1 & 1 & 2 & 0 & 0 & & \\
\hline Formal & 1 & 4 & 4 & 13 & 9 & 5 & 3 & & \\
\hline $\begin{array}{l}\text { Formal \& } \\
\text { informal }\end{array}$ & 0 & 1 & 2 & 9 & 6 & 2 & 0 & $\begin{array}{c}0,90 \\
2\end{array}$ & $-0,16$ \\
\hline Less & 0 & 3 & 3 & 11 & 9 & 2 & 0 & 0,37 & (110 \\
\hline Good & 1 & 2 & 3 & 11 & 6 & 5 & 3 & 4 & 0,118 \\
\hline
\end{tabular}

Table 4. Results of multivariat analysis between history of fish-based complentary food provision, compassion, and history of exclusive breastfeeding with the cognitive level

\begin{tabular}{lcccccc}
\hline \multirow{2}{*}{ Variables } & \multicolumn{2}{c}{ Model I } & \multicolumn{2}{c}{ Model II } & \multicolumn{2}{c}{ Model III } \\
\cline { 2 - 7 } & $\boldsymbol{p}$ value & $\mathbf{r}^{\mathbf{2}}$ & $\boldsymbol{p}$ value & $\mathbf{r}^{\mathbf{2}}$ & $\boldsymbol{p}$ value & $\mathbf{r}^{\mathbf{2}}$ \\
\hline $\begin{array}{l}\text { Fish-based } \\
\text { complementary food }\end{array}$ & 0,155 & & 0,108 & & & \\
Compassion & 0,167 & 0,608 & & 0,543 & 0,096 & 0,412 \\
$\begin{array}{l}\text { Exclusive } \\
\text { breastfeeding }\end{array}$ & 0,03 & & 0,005 & & 0,001 & \\
\hline
\end{tabular}

Based on table 2, the $\mathrm{p}$ value for the history of fish-based complementary food provision was obtained, the history of exclusive breastfeeding and maternal care or affection (compassion) $<0.05$, 
meaning that there was a significant correlation between fish-based complementary food history, exclusive breastfeeding history and maternal care or affection for the cognitive level of the child.

Based on table 3, it can be seen that, the $p$ value on the parenting variables, maternal knowledge about fish-based complementary foods, and the provision of additional education (sharpening) $>0.05$, meaning there was no significant correlation between parenting, maternal knowledge about fish-based complementary foods, and giving additional education (sharpening) to the cognitive level of the child.

Based on table 4, it can be concluded that the history of exclusive breastfeeding had the greatest influence on the cognitive level of the child. The multivariate table shows that the history of exclusive breastfeeding had the most significant correlation to the cognitive level with $\mathrm{p}$ value $=$ 0.005 and $r^{2}=0.543$ which meant $54.3 \%$ of the cognitive level was influenced by a history of exclusive breastfeeding and a history of fish-based complementary food provision so that can be used as a reference to find out the variables which has highest influence to children's cognitive level.

The results of the study with the spearman rank bivariate analysis showed that there was a significant correlation between cognitive level with history of fish-based complementary food provision. Fish-based complementary food has protein content consisting of essential fatty acids, namely omega-3 and DHA (Docosehexaenoic Acid) which functions to process brain growth and development, so that the intake of omega-3 and DHA has a very important role for children's intelligence in the future (Andriani \& Wirjatmaji, 2012).

The results of the analysis of this study indicate that there was no significant correlation between parenting, mother's knowledge about fishbased compelentary food provision and the provision of additional education (sharpening) to the cognitive level. The results of other studies state that parenting is more influential on emotional or affective intelligence than children's intellectual or cognitive intelligence (Aghili \& Kashani, 2011; Hidayah, Yunita, \& Wiji Utami 2013). The provision of additional education (sharpening) also does not affect intellectual intelligence. Group guidance (informal group tutoring) is effective for increasing students' emotional or affective intelligence, so it does not significantly affect children's cognitive (Nurnaningsih, 2011).

Based on the results of the analysis, there was a significant correlation between fish-based complementary food provision, the history of exclusive breastfeeding and maternal care or compassion to the cognitive level. Exclusive breastfeeding increases intellectual intelligence in all aspects of figures, verbal and numerical. The concentration of long chain unsaturated fatty acids that are useful for brain growth and development and Insulin like growth factor I (IGF-I) which play a role in the growth of children and have anabolic effects or build new cells and maintain body tissue in adults, more contained in breast milk rather than formula milk (Kramer et al., 2008).

Mother's care or compassion has a significant correlation with children's cognitive. Parental care patterns, namely maternal support in feeding practices, psychosocial stimuli, hygiene practices, and toddler health care influence the 
nutritional status of children in which the nutritional status of these children can affect children's cognitive development (Amalia, 2016). Mother's care or compassion has a significant correlation with children's cognitive and emotional intelligence. Parents are the first fostering place in a child's life. The best condition for children is a condition full of happiness and enthusiasm which is a condition where they have harmonious interpersonal relationships. Circumstances that are full of support help children develop all their potential, put all their skills and talents to full use (Meriyati, 2014).

The results of multivariate analysis of logistic regression showed that history of exclusive breastfeeding had a greater influence on cognitive level compared to a history of fish-based complementary food provision and maternal care or compassion. Fish-based complementary food is indeed a nutrient that can optimize the growth and cognitive development of children, but there are other factors that are more influential on cognitive such as maternal care or affection (compassion), exclusive breastfeeding history, genetics, and other factors (Soetjiningsih, 2013).

The nutrient components contained in breast milk influence the development of behavior and cognitive of children. One of the most important substances in terms of children's behavioral and cognitive development is taurine, an amino acid derivative found in breast milk, the most abundant amino acid in the brain, retina, muscle tissue, and other organs throughout the body (Ripps \& Shen, 2012). Different studies have found that high-educated mothers have a greater chance of having high-intelligence children than mothers who give exclusive breastfeeding. This study states that each individual is a hereditary product that inherits genetic characteristics from parents and environmental factors so that children's intelligence will be inherited from the mother and influenced by the education of the mother of the child (Said \& Pratomo, 2013).

\section{CONCLUSION}

There is correlation that is theoretically significant but not statistically significant and relatively weak correlation between history of fishbased complementary food and compassion or parental care with children's cognitive level. There is correlation that is theoretically and statistically significant and relatively strong correlation between exclusive breastfeeding with children's cognitive level.

For mothers it is recommended to give exclusive breastfeeding to 0-6 months old children. Parents are advised to provide care or affection for children during the growth period and are advised to give fish-based complenetary food at the age of 6-24 months.

\section{REFERENCE}

Aghili, M., and Kashani, M. (2011). Study of the relationship between parenting style, and children's emotional intelligence and selfefficacy. Journal of American Science, 7 (9): 380-384.

Amalia, H. and Mardiana, M. (2016). Hubungan Pola Asuh Gizi Ibu dengan Status Gizi Balita di Wilayah Kerja Puskesmas Lamper Tengah Kota Semarang. Journal of Health Education, $1(2): 8-13$. 
Andriani, M., and Wirjatmaji, B. (2012). Pengantar Gizi Masyarakat. Jakarta: Kencana Prenada Media Group.

Hidayah, R., Yunita, E., and Wiji Utami , Y. (2013). Hubungan Pola Asuh Orangtua dengan Kecerdasan Emosional Anak Usia Prasekolah (4-6 Tahun) di TK Senaputra Kota Malang. Jurnal Keperawatan, 4 (2): 131-135.

Kramer, M. S., Aboud, F., Mironova, E., Vanilovich, I., Platt, R. W., and Matush, L. Breastfeeding and Child Cognitive Development: New Evidence From a Large Randomized Trial. Archives of General Psychiatry, 65 (5): 578-584.

Larsen, R., Eilertsen, K. E., and Elvevoll, E. O. (2011). Health benefits of marine foods and ingredients. Biotechnol Adv, 29 (5): 508-518.
Meriyati. (2014). Peran Orang Tua dalam Mengembangkan Kecerdasan Emosional Anak. Jurnal Bimbingan dan Konseling, 1 (1): 33-39.

Nurnaningsih. (2011). Bimbingan Kelompok Untuk Meningkatkan Kecerdasan Emosional Siswa. Jurnal Universitas Pendidikan Bandung, 1 (8): 268-278.

Ripps, H., and Shen, W. (2012). Review: taurine: a "very essential" amino acid. Mol Vis, 18 (22): 2673-2686.

Said, M., and Pratomo, H. (2013). Pendidikan Ibu dan Durasi Pemberian Air Susu Ibu dalam Peningkatan Kecerdasan Siswa Usia Sekolah Dasar. Kesmas: National Public Health Journal, 8 (4): 169-173.

Soetjiningsih R. G. (2013). Tumbuh Kembang Anak Edisi 2. Jakarta: EGC. 